\title{
THE POWER OF SHARED PHILOSOPHY: A STUDY OF MIDWIVES' PERCEPTIONS OF ALTERNATIVE BIRTH CARE IN NORWAY
}

Published in 2016 British Journal of Midwifery 24 (2): 1-7.

Key words: Empowerment, alternative birth care, pregnancy care, birth, postnatal

\section{Abstract}

Aim: The aim of this study was to explore important factors that promote the best possible health for mother and child during pregnancy, birth and post-birth in an alternative birth clinic $(\mathrm{ABC})$ in Norway.

Design: We identified factors important in ABCs according to the holistic treatment model in the philosophy of $\mathrm{ABCs}$ using in-depth interviews.

Methods: Transcription and text condensation were achieved by looking for text to find themes and subthemes to explore daily activities and role of empowerment.

Results: The most important factors were teaching the mothers how to cope, mentally and practically, and being true to the philosophy of $\mathrm{ABCs}$. The factors connected to empowerment of the mothers were strengthening the ability to make good decisions, their ability to cope practically and the midwives' ability to step back and let the mothers gradually take responsibility.

Conclusion: Our ABC reflected theoretical fundaments for ABCs. Midwives shared common opinions of important factors empowering the mothers. 


\section{Introduction}

Implementing safe maternal care is a worldwide concern. Optimal care should be provided antenatal, intrapartum and post partum and include both the mother and infant (WHO, 1994, 1996). In Western countries, births usually take place in hospitals with equipment and personnel to deal with unexpected situations, relationing to health concerns (Kunnskapssenteret, 2006). The Norwegian Directory of Health emphasizes the continuity of care. Beyond evidence-based medicine in midwifery, there is also a need to address underpinning theory (Halldorsdottir and Karlsdottir, 2011). Holistic care is explained as to what extent the health personnel endorse patients' interaction between physically, mentally, socially, and spiritually state of mind (Haugan and Rannestad, 2014).

An alternative birth clinic (ABC) hold strong elements of supporting empowerment alongside the professional integrity of midwives. ABCs seek to present a less-routinised, homely atmosphere compared to hospital units with a special focus on choices of colour, furniture, plants to mention some of the inventory (Homer, 2013). ABCs support normal birth as the main standard for giving birth. WHO (2014) defines normal birth as "spontaneous in onset, low-risk at the start of labor are maining so throughout labor and delivery. After birth mother and infant are in good condition". Important elements in ABCs are the philosophy of mother and midwife making decisions together, a holistic environment to support the feeling of a safe haven, fewest possible interventions in the birth process and the mothers having optimal control (Cook, 2012). Not all mothers can be admitted to ABC. Women with a former history of birth complications, who want pharmacological pain relief or expecting more than one child are excluded from ABCs (Holan, 2000). 
Empowerment is defined as helping people to assert control of factors affecting their lives

(Gibson, 1991). Several studies point to important factors underpinning midwifery (Bergsjø et al, 2006, Amber, 2008, Lindgren and Erlandsson, 2010);

- being supportive

- having a guiding role in the process of life and body changes associated with birth

- choosing guiding solutions to empower the mother

- giving practical advice on/safe environments to care for physical and mental health issues

- empowerment to be in control and experience birth as a natural process, despite the discomfort

The pregnancy and birth process are extremely important, influencing each individual mother's state of mind and social interactions and requiring a holistic approach to care (Hermansson and Mårtensson, 2011). Hewitt and Hangsleben (2011) point to the mother's coping abilities in techniques during childbirth and care for the newborn (Waldenstrøm et al, 2004). Negative birth experiences are associated with post traumatic stress disorder (GarthusNiegel et al, 2013), and post-partum depression (Cindy-Lee and Leinic, 2006).

Research questions:

Which daily activities in an $\mathrm{ABC}$ reflect important factors already reported from research?

Which factors are reported by midwives to promote empowerment in an $\mathrm{ABC}$ ? 
The aim is to explore whether important factors promoting optimal health for mother and child during pregnancy, birth and post-birth are implemented in ABC.

\section{Methodology}

\section{Setting of the study}

The $\mathrm{ABC}$ was situated in a medium-sized town. The $\mathrm{ABC}$ admitted 500 women each year. The pregnant women need to apply for admission to the ABC. The midwives were employed at the $\mathrm{ABC}$ and they also performed the pregnancy and post-birth examinations of mother and baby. The admitted women stay approximately 48 hours in the $\mathrm{ABC}$ before discharge. The rooms in the $\mathrm{ABC}$ have a homely environment with enough space for their next of kin to stay or even sleep.

\section{Interviews}

The interviews took place in the ABC. Five midwives were interviewed with each interview lasting 45 to 60 minutes.

\section{Design of the study}

Since no other studies were found to tell if the midwives' practice was in concordance with the philosophy of ABCs, and the role of empowerment, the design of the study was an exploratory, qualitative study in order to gain insight.

We identified important factors in ABCs according to the holistic treatment model in the philosophy of ABCs. In-depth interviews with midwives were performed. Our method provided information on the integration of theory in the clinic and may be described as validation of the clinical work of the midwives in the clinic because the midwives seek to 
provide care according to their philosophy . The exploratory part was to identify factors not described in the theoretical framework.

\section{Sample}

The first author requested to do a study in the $\mathrm{ABC}$ and provided both oral and written information about the study. Permission from leaders of the ABC, and the Norwegian Social Science Data Services was sought before the study started.

The semi-structured in-depth interview guide covered topics such as descriptions of the ideology of $\mathrm{ABC}$, what comprised a normal day, and the importance of the relationship between midwives and pregnant women. All questions were open-ended to collect an optimal degree of information. The role of the interview guide was to gather sufficient data to answer our research questions.

\section{Data collection}

Interviews were conducted on five occasions and audiotaped. The interviews were ranscribed and the analysis identified text to enlighten the categories from the literature as well as create new categories. In the two last interviews, no new information came up, suggesting saturation of the data.

\section{Data analysis}

The aim of the analysis was connecting the empirical statements, results, and accurately interpreting the midwives' statements. The first author completed the analysis. The material was decontextualized, a process of extracting text, signs or meaning from its original context to establish meaningful associations (Malterud, 2003). This yielded factors supplying our theoretical understanding. Kvale (2001) and Bengtsson (2006) describe three contexts for 
interpretation of text: self-understanding, critical and theoretical understanding. The three different contexts can be understood separately but mostly they help to interpret the interviews in a more holistic view of the material and foregrounds unique and common experiences and statements.

\section{Limitations}

The informants were few $(\mathrm{N}=5)$. The midwives were supportive of the philosophy of $\mathrm{ABCs}$ which could constitute bias. As only midwives from an $\mathrm{ABC}$ were interviewed and not midwives from an ordinary birth clinic, we have no information whether both groups shared the same philosophy. We also need to report that when the midwives reported holism they focused on practical nursing without considering cultural context.

\section{Results}

Our first research question was the implementation of the philosophy of $\mathrm{ABCs}$ in the daily work of midwives. (Table 1)

Table 1. Daily work in an ABC reflecting the philosophy of ABCs.

\begin{tabular}{|l|l|l|}
\hline Categories & \multicolumn{2}{|c|}{ Important actions for good outcome } \\
\hline Coping of the & Safe environments & Trustful environment with midwives \\
& Good information & Accurate information to prepare birth \\
& Practical training & Midwives as practical role models \\
\hline Environmental & Homely atmosphere for mothers & Personal, homely athmosphere \\
\hline
\end{tabular}




\begin{tabular}{|c|c|c|}
\hline issues & & Proper hygienic standards \\
\hline $\begin{array}{l}\text { Close distance to a } \\
\text { hospital }\end{array}$ & Low risk pregnancies & $\begin{array}{l}\text { Births without identified risk for } \\
\text { complications }\end{array}$ \\
\hline $\begin{array}{l}\text { Non medication if } \\
\text { possible }\end{array}$ & $\begin{array}{l}\text { Natural mechanisms in pain } \\
\text { coping }\end{array}$ & $\begin{array}{l}\text { Physical antenatal activities } \\
\text { Finding optimal position for birth } \\
\text { Massages, acupuncture }\end{array}$ \\
\hline *Relational context & $\begin{array}{l}\text { Shared philosophy } \\
\text { Holistic care } \\
\text { Adequate time for engagement } \\
\text { Trust building } \\
\text { Information sharing }\end{array}$ & $\begin{array}{l}\text { Information exchange } \\
\text { Build on maternal preferences } \\
\text { Follow the philosophy of ABCs }\end{array}$ \\
\hline Summary & $\begin{array}{l}\text { Shared commitment to the } \\
\text { philosophy of ABCs } \\
\text { Shared information with the } \\
\text { mothers }\end{array}$ & $\begin{array}{l}\text { Shared philosophy lessens the risk of } \\
\text { contradictionary information and } \\
\text { provides optimal coping }\end{array}$ \\
\hline
\end{tabular}

* Issues not identified in the initial literature search

According to our midwives, mothers should feel safe in order to accept and learn from information, practical training of tasks, and how to use their own bodies in reducing pain in the birth process. All midwives emphasized the homely atmosphere as an important factor in the mothers' experiences of having some sense of equality. The midwives were under the strong impression that the mothers did not care too much if they had to relate to different midwives as long as the midwives shared the same ideas and philosophy. 
We searched for factors promoting empowerment of the mothers admitted to an ABC. (Table 2)

Table 2. Factors promoting empowerment in an ABC

\begin{tabular}{|c|c|c|}
\hline Categories & \multicolumn{2}{|c|}{ Important actions for good outcome } \\
\hline The mother's resources & $\begin{array}{l}\text { Using resources as fundament } \\
\text { for coping }\end{array}$ & $\begin{array}{l}\text { Build on existing knowledge of the mothers to } \\
\text { ensure the best possible birth experience and } \\
\text { also as a fundament for practical coping both } \\
\text { in the birth process but also in order to take } \\
\text { care of the newborn. }\end{array}$ \\
\hline $\begin{array}{l}\text { The mother's ability to } \\
\text { make good decisions }\end{array}$ & $\begin{array}{l}\text { Achieving conducive } \\
\text { environment } \\
\text { Providing pertinent } \\
\text { information } \\
\text { Teaching the mother how to } \\
\text { carry out key tasks }\end{array}$ & $\begin{array}{l}\text { Midwives should facilitate communication } \\
\text { Mothers should be heard and given the } \\
\text { opportunity to speak their mind } \\
\text { Midwives should be role models in practical } \\
\text { coping. }\end{array}$ \\
\hline $\begin{array}{l}\text { The mother's practical } \\
\text { coping }\end{array}$ & $\begin{array}{l}\text { Teaching and practising } \\
\text { necessary tasks in birth giving } \\
\text { and taking care of the baby }\end{array}$ & $\begin{array}{l}\text { Midwives should identify each mothers } \\
\text { abilities to learn and provide information } \\
\text { accordingly }\end{array}$ \\
\hline $\begin{array}{l}\text { *The midwife's ability } \\
\text { to step back in favour } \\
\text { of the mother's own } \\
\text { coping and decision }\end{array}$ & $\begin{array}{l}\text { Increasing the level of maternal } \\
\text { autonomy, independent actions } \\
\text { and decision-making to } \\
\text { advance confidence in taking }\end{array}$ & $\begin{array}{l}\text { When two coping solutions are close to equal, } \\
\text { the mothers' choice should be heard. as long } \\
\text { as the solution do not represent any risk to } \\
\text { mother or child. }\end{array}$ \\
\hline
\end{tabular}




\begin{tabular}{|l|l|l|}
\hline making & care of their baby & Monitoring pregnancy, being a \\
* The role of the & good listener, showing interest & Midwives should \\
be patient and be near to the mothers by being \\
good listeners and \\
Summary
\end{tabular}

* Findings not identified in our preliminary theoretical understanding

Our midwives met each mother with respect and an honest wish to empower them, both to endure birth and enable learning practical tasks in taking good care of their babies. The identification of each mother's resources is reported as a fundament for coping. The ability to step back and allow the mothers to gain confidence in their coping was stated as important.

\section{Discussion}

Empirical research provides us with an up-to-date understanding of the important factors in pregnancy, childbirth, and postbirth (Waldenstrøm et al., 2004, Hewitt and Hangsleben, 2011, 
Hermansson and Mårtensson, 2011, Bergsjø et al 2006, Amber, 2008, Lindgren and Erlandsson, 2010). and these correspond well with the factors the ABCs consider as valuable in daily care.

Our midwives agreed that $\mathrm{ABCs}$ provide holistic care to mothers and that women in birth will not be met in a paternal or maternal way (Sørensen \& Graff-Iversen, 2001), but as equal to the midwives.

\section{Coping}

To provide the mothers with the resources to make good decisions, the most important factor seemed to be information, practical learning on how to handle pain in the labour process, and handle the baby after birth (Waldenstrøm et al, 2004). One informant commented: I try to use the mother's resources and make her confident that she is capable of giving birth and to raise her baby. Knowing what probably will happen during birth and after the baby is born will provide the women with a higher sense of control and ability to make decisions suitable for each individual mother. Another informant stated: .... we are conscious of including the mother in matters concerning her. She also takes part in discussions and learns why we suggest the different actions...

\section{Environmental issues}

The homely atmosphere in an ABC (Homer, 2013) contributes to a relaxed atmosphere and communication, which likely results in lowering stress levels among the mothers. One of the

midwives stated: ...many of the mothers tell us that they feel safe and comfortable here... The 
ABCs must be carefully planned to meet the hygienic standards in birth settings. The midwives creatively decorated the $\mathrm{ABC}$ in a homely manner without breaking any hygienic principles. This reinforced knowledge around hygiene that the mothers could apply in their own homes.

\section{Close distance to hospital}

The ABCs are not equipped to deal with emergency situations, which can occur during labour although women admitted to these facilities are considered as low risk births. Midwives in ABCs have high standards and a high degree of autonomy, according to our midwives and supported by Adams (2006). Midwives are trained to discover symptoms which are deviation from the normal.. One respondent noted: I must have the professional integrity to dare to make decisions on my own.... Given that the $\mathrm{ABC}$ in our study was located close to a specialized, medical hospital it is reasonable that the distance to the ordinary hospital was not a topic. If the $\mathrm{ABC}$ was located further away from the ordinary hospital the midwives in the $\mathrm{ABC}$ would probably focus more on emergency situations and closeness to an ordinary hospital birth clinic.

Non-medication if possible

Our midwives report that $\mathrm{ABC}$ midwives are highly skilled in alternative methods to reduce or cope with pain during labour, like giving birth under water in a bathtub, acupuncture, or massages.

A recent study suggests that complimentary medicine should be an option in pain reduction during the birth process (Steel et al, 2013). One of our midwives said: It is extremely 
satisfying working with mothers who are determined to cope with the birth by the use of own body as the sole instrument.

\section{Relational context}

$\mathrm{ABC}$ units assign one midwife to be the primary care giver. Continuity of carer is the way forward, it provides safe, sensitive, respectful midwifery care. Both women and midwifery likes it and it works, but few places want to implement continuity of carer schemes (Warren, 2003, Aune et al, 2011).

Due to birth time, midwives working hours, vacations etc, the goal of one midwife following one mother is not always possible. However, sharing the same philosophy and caring practice also provides a sense of security or coherence in the mothers. As one of the midwives put it: It seems like the mothers don't mind which midwife is present. They say that all of us share the same philosophy and most of the mothers have good relations to all. Another important aspect is time for the mother and midwife to interact. This will ease the birth process, which in some cases can be rather stressful. Stress in mothers could transfer to the babies and result in complications in the birth process (Garthus-Niegel et al, 2013). One of our midwives in the $\mathrm{ABC}$ formulates: ...I have more time and I am more patient....

The mothers seem to value the shared philosophy between the midwives more than the continuity of having one midwife during the process. It seems as if relational context is important but relations are built on the fundament of midwives having the same ideas, the same respect and the same sharing of knowledge with the mothers, rather than the sole presence of one midwife. 
Empowerment theory emphasizes the process of health personnel making decisions to enable mothers to gain control and being able to cope in a situation that is somewhat "out of control".

\section{The mothers' resources}

Our midwives reported that the ability of midwives to identify factors that can be controlled or coped with by the mother in birth is crucial to nurture empowerment. Challenges can arise if complications in the birth process occur. Specialized help may be required and mothers, socialised into handling everything from a normal birth perspective, may refuse help. With any complications, the mother in labour is transferred to the regular hospital birth clinic in order to deal with or avoid an emergencysituation. The mothers have no choice in this process and the experience and professional judgment of the midwives is paramount in decisions.

\section{Mothers' ability to make good decisions}

Another key element in the philosophy of empowerment is to establish the mother's own responsibility to find the right solutions to challenges (Gibson, 1991). As ABCs often focus on natural birth on the mother's own terms, the approaches are different in the sense of normalizing the birth compared to a regular birth unit. Our midwives focused on individual information and guidance as the most important factor to empower the women`s own coping, like knowledge about alternative ways of pain coping, like acupuncture, massages, different birth positions - what the midwife can/cannot do in different situations. 
The mother's practical coping

We cannot expect mothers to make good decisions on how to cope if they lack knowledge of basic medical issues that can arise during the birth process. In an atmosphere of equality between the midwife and the mother, the professional knowledge of the midwife must be acknowledged as well as the mother's expert views of the perceptions and emotions in the birth process and build on this knowledge to empower coping processes. The professional principle of saving life and promoting health in mother and child would always supervene if survival is compromised.

The midwife's ability to "step back"

Our midwives emphasized the importance of their stepping back and allowing the mothers to decide how to cope to empower and enhance maternal confidence.

\section{The midwife's role}

The role of the midwife in an $\mathrm{ABC}$ compared to more traditional, hospital-based birth care settings, is quite different. The midwife in ABCs will need to keep up to date in evidencebased knowledge for both general midwifery and that related to specialized birth units such as ABC's.

None of our midwives commented on the need to be close to an ordinary hospital birth unit in case of complications probably because the $\mathrm{ABC}$ was situated close to a medical hospital. 
Although midwives in an $\mathrm{ABC}$ are enthusiastic in the use of complementary and alternative medicine there remains only limited research in this field (Hall et al, 2012).

\section{Conclusion}

The activities of our midwives reflected all the issues described in literature to date, like high standards and autonomy, relational cooperation, practical and mental coping, and sharing the same philosophy and framework and were reported as more important than one-to-one contact throughout the pregnancy. Guidance to cope mentally and practically was considered the most important for empowerment.

ABCs seem to provide a relational service that affords a meaningful bridge between the familiarity of home, their care by midwives and the translation of new knowledge about caring for a baby back into the mother's home context. Our study could be a reminder to midwives in $\mathrm{ABCs}$ to be aware of the importance of the original philosophy which should be further developed.

\section{Ethical aspects and conflict of interest}

The study was registered at the Norwegian Social Science Data Services. All the midwives were informed of their right to withdraw from the study. The midwives were given written information of the study and contact information for the first author. The authors report no conflicting interests of any kind. 


\section{References}

Adams J. (2006). An exploratory study of complementary and alternative medicine in hospital midwifery: Models of care and professional struggle. Complementary therapies in Clinical Practice. ; 12, 40-47.

Amber T, Pewitt BA. (2008). The Experience of Perinatal Care at a Birthing Center: A Qualitative Pilot Study. J Perinat Educ.17(3), 42-50.

Antonovsky A. (1979). Health, Stress and Coping. San Francisco, Washington, London: Jossey-Bass Publishers.

Aune I, Dahlberg U, Ingebrigtsen O. (2011). Relational continuity as a model of care in practical midwifery studies. British Journal of Midwifery, 19(8), 515-524.

Bengtsson J .(2006). En livsverdenstilnaerming for helsevitenskapelig forskning. I: Livsverdensfenomenologiske bidrag. Norway. Hoegskoleforlaget.

Bergsjø P, Heiberg M, Telje J and Thesen J. (2006). Svangerskapsomsorg. Oslo Gyldendal Norsk Forlag.

Cindy-Lee D, Leinic CL. (2006).Postpartum Depression Help-Seeking Barriers and Maternal TreatmentPreferences: A Qualitative Systematic Review Birth.33 (4), 323-331.

Cook K (2012). The Impact of Choice and Control on Women's Childbirth Experiences. $J$ Perinat Educ. 21(3), 158-168. 
Garthus-Niegel S, von Soest T, Vollrath ME, Eberhard-Gran M.( 2013). The impact of subjective birth experiences on post-traumatic stress symptoms: a longitudinal study. Arch Womens Ment Health. Feb;16(1):1-10. doi: 10.1007/s00737-012-0301-3.

Gibson CH.(1991). A concept analysis of empowerment. Journal of Advanced Nursing. 16, 354-361.

Halldorsdottir S1, Karlsdottir SI. (2011). The primacy of the good midwife in midwifery services: an evolving theory of professionalism in midwifery. Scand J Caring Sci.25(4), 80617.

Hall HG, McKenna LG, Griffiths DL. (2012). Midwives support for Complementary and Alternative Medicine: A literature review. Women and Birth. 25(4), 12.

Haugan, G. and Rannestad, T. (red.) (2014). Helsefremming i kommunehelsetjenesten (Health promotion in the community services). Cappelen Damm Akademisk.

Hermansson E and Mårtensson L. (2011). Empowerment in the midwifery context - a consept analysis. Midwifery. 27, 811-816.

Hewitt MA. and Hangsleben KL. (2011). Nurse-midwives in a hospital birth center. $J$ of Nurse-Midwifery. 26(5), 21-29. 
Holan S.(2000). Det nye livet. Svangerskap, fødsel og barseltid. Bergen: Fagbokforlaget Vigmostad and Bjørke AS.

Homer CSE (2013). Home-like environment for labour and birth: benefits for women and babies. Evid Based Med.

Kunnskapssenteret (2006).Jordmorstyrte fødestuer (Birth clinics run by midwives) . Report from the Norwegian National Centre of Knowledge. Nasjonalt kunnskapssenter for helsetjenesten (16).

Kvale S (2001).Det kvalitative forskningsintervju (The qualitative research interview) . Oslo. Gyldendal Akademisk AS

Lindgren H, Erlandsson K . (2010). Women's Experiences of Empowerment in a Planned Home Birth: A Swedish Population-based Study. Women`s Health Nursing. 37(4), 309-317.

Malterud K. (2003).Kvalitative metoder i medisinsk forskning (Qualitative methods in medical research). Oslo Universitetsforlaget

Steel A, Adams J, Sibbritt D, Broom A, Gallois C and Frawley J. (2013). Managing the pain of labour: factors associated with the use of labour pain management for pregnant Australian women. Health Expect. 4.

Sørensen M. and Graff-Iversen S. (2001). Hvordan stimulere til helsefremmende atferd (How to stimulate health promoting behaviour)? Tidsskrift Norsk Lageforening. 121, 720-4. 
Waldenström U, Hildingsson I, Rubertsson C and Rådestad I.A (2004).Negative Birth Experience: Prevalence and Risk Factors in a National Sample. Birth. 31, 17-27.

Waldenstrøm U. (1993). Føda barn på ABC Giving birth in an ABC). Barnmorskars upplevelser av ett annorlunda arbetssett (Midwives experiences in a different clinical setting). Stockholm: Svenska hälso- och sjukvårdens tjänestemännaforbund.

Warren, C (2003). Exploring the value of midwifery conitnuity of carer. British journal of midwifery, vol 11 No 10.

World Health Organization. (1994). Safe Motherhood. Mother-baby Package: Implementing safe motherhood in countries. Practical guide. Geneva.Maternal health and safe motherhood programme. Division of family health.

World Health Organization (1996). Care in normal birth: a practical guide. Geneva: Division of family health.

World Health Organization (2014). Recommendations for augmentation of labour.ISBN: 978 9241507363. 